Research Paper

\title{
Epidemiological and Clinical Features of Patients Suffering from Severe Pneumonia Caused by RSV in the Respiratory Center of Vietnam National Children's Hospital
}

\author{
Le Thi Hong Hanh ${ }^{*}$, Hoang Thi Thu Hang, \\ Nguyen Thi Le, Hoang Phuong Thanh, Dang Mai Lien \\ Vietnam National Children's Hospital, 18/879 La Thanh, Dong Da, Hanoi, Vietnam \\ Received 11 August 2020 \\ Revised 22 August 2020; Accepted 28 August 2020
}

\begin{abstract}
Background/Purpose: Pneumonia is a common respiratory and life-threatening disease in pediatrics. Virus is an important cause of pneumonia in children, of which Respiratory syncytial virus (RSV) is the most common cause. The aim of this research is to access the clinical, epidemiological features and risk factors of patients suffering from RSV severe pneumonia.

Methods: We studied 250 patients suffering from severe pneumonia caused by RSV from June 2019 to December 2019 in the Respiratory Center of Vietnam National Children's Hospital.

Results: In Respiratory Center of our hospital, 3472 hospitalizations caused by pneumonia occurred in the last 6 months in 2019; 7.2\% of these caused by RSV severe pneumonia. Pneumonia caused by RSV occurred most in male $(66,7 \%)$, the rate of male/female $=2 / 1$. The mean age was 4,94 $\pm 6,04$ months. The prevalence of RSV in age groups is, respectively, as follows: less than 3 months (21,3\%), from 3 months to 6 months $(23,4 \%)$, from 6 months to 12 months (27\%), from 12 months to 24 months (19\%), over 2 years $(9,3 \%)$. The most common symptoms which were accounted for over $80 \%$ were rhinorrhea, cough, wheeze, tachypnea and chest recession. The rate of admission increased sharply in December with $25.1 \%$ of cases. All hospitalized patients had respiratory distress symptoms with the changes in blood gas analysis, accounting for $59.2 \%$ of hypercapnia. The mean of hospitalization was $6,2 \pm 7,4$ days.

Conclusions: the rate of RSV infection increased in the last 6 months in 2019. Most of patients who less than 1 year of age were admitted to hospital because of severe clinical symptoms and respiratory distress. Risk factors were related to the severity of RSV severe pneumonia were: premature, malnutrition, bronchopulmonary dysplasia.
\end{abstract}

Keywords: Severe pneumonia; RSV.

\footnotetext{
* Corresponding author.

E-mail address: lehonghanhbvnhi@yahoo.com

https://doi.org/10.25073/jprp.v4i5.225
} 


\title{
Đặc điểm dịch tễ học lâm sàng ở trẻ viêm phổi nặng có nhiễm RSV tại Trung tâm Hô hấp Bệnh viện Nhi Trung ương
}

\author{
Lê Thị Hồng Hanh*, Hoàng Thị Thu Hằng, \\ Nguyễn Thị Lê, Hoàng Phương Thanh, Đặng Mai Liên
}

Bệnh viện Nhi Trung uoong, 18/879 La Thành, Đống Đa, Hà Nội, Việt Nam

Nhận ngày 11 tháng 8 năm 2020

Chỉnh sửa ngày 22 tháng 8 năm 2020; Chấp nhận đăng ngày 28 tháng 8 năm 2020

\section{Tóm tắt}

Đặt vấn đề/Muc tiêu:Viêm phổi là bệnh lý thường gặp và là nguyên nhân chính gây tử vong ở trẻ em . Vi rút là nguyên nhân quan trọng gây viêm phổi ở trẻ em , trong đó RSV là nguyên nhân thường gặp nhất. Chúng tôi nghiên cứu một số đặc điểm dịch tễ, lâm sàng, cận lâm sàng và các yếu tố liên quan ở các trẻ viêm phổi nặng có nhiễm RSV.

Phuơng pháp: Nghiên cứu 250 bệnh nhân viêm phổi nặng có nhiễm RSV trong thời gian từ tháng 6 năm 2019 đến tháng 12 năm 2019.

Kết quả: Tại Trung tâm Hô hấp Bệnh viện Nhi Trung ương, trong 6 tháng cuối năm 2019, có 3472 ca nhập viện vì viêm phổi, trong đó $7,2 \%$ là viêm phổi nặng do RSV. Bệnh chủ yếu gặp

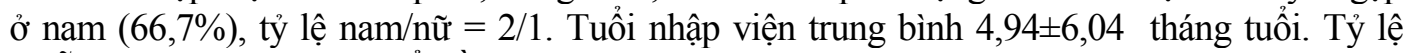
nhiễm RSV ở các nhóm tuổi lần lượt là $<3$ tháng $(21,3 \%)$, từ 3 tháng - 6 tháng $(23,4 \%)$, từ 6 tháng - 12 tháng (27\%), từ 12 tháng - 24 tháng (19\%), trên 2 tuổi 9,3\%. Các triệu chứng lâm sàng hay gặp ho, chảy mũi, khò khè, thở nhanh, rút lõm lồng ngực đều chiếm tỷ lệ cao $(>80 \%)$. Tỷ lệ bệnh tăng cao đột biến vào tháng 12 với $25,1 \%$ số trường hợp. Các trẻ nhập viện đều có triệu chứng $\mathrm{SHH}$ với biến đổi khí máu hay gặp là tăng $\mathrm{CO}_{2}$ chiếm $59,2 \%$. Thời gian nằm viện trung bình $6,2 \pm 7,4$ ngày.

Kết luận: Tỷ lệ nhiễm RSV gia tăng 6 tháng cuối năm 2019, trẻ nhập viện chủ yếu là ở nhóm trẻ dưới 1 tuổi, với các triệu chứng nặng, suy hô hấp nặng ở các mức độ khác nhau. Một số yếu tố liên quan như đẻ non, suy dinh dưỡng, loạn sản phế quản phổi làm gia tăng tỷ lệ mắc RSV và mức độ nặng ở các trẻ viêm phổi nhập viện.

Tù khóa: Viêm phổi nặng, RSV.

\section{1. Đặt vấn đề}

Theo báo cáo của Tổ chức Y tế thế giới năm 2006, trẻ em dưới 5 tuổi ở các nước đang phát triển, nhiễm khuẩn hô hấp dưới cấp tính đứng hàng đầu trong các nguyên nhân gây tử vong ở lứa tuổi này $[1,2]$. Ở trẻ em, tỷ lệ mắc viêm phổi vi rút khá cao,

* Tác giả liên hệ.

Địa chi email: lehonghanhbvnhi@yahoo.com

https://doi.org/10.25073/jprp.v4i5.225 chiếm 60 đến $70 \%$ [1,3]. Những vi rút gây viêm phổi hay gặp nhất như vi rút hợp bào hô hấp (RSV). Trong năm 2005 ước tính có khoảng 33,8 triệu trường hợp nhiễm trùng đường hô hấp dưới do nhiềm RSV xảy ra trên toàn thế giới ở trẻ dưới 5 tuổi, với ít nhất 3,4 triệu trẻ bị nhiễm trùng đường hô hấp dưới cần phải nhập viện điều trị và có khoảng 66000 - 199000 trẻ dưới 5 tuổi chết vì nhiễm trùng đường hô hấp dưới do nhiễm RSV [4]. Việc nghiên cứu và cập nhật tình 
hình viêm phổi do vi rút RSV tại các đơn vị điều trị về hô hấp là rất cần thiết . Tỷ lệ nhiễm vi rút RSV đặc biệt gia tăng vào các mùa thu, đông. Trung tâm hô hấp Bệnh viện Nhi Trung ương trong 6 tháng cuối năm cũng tiếp nhận và điều trị rất nhiều bệnh nhân nhiễm RSV. Chính vì thế, chúng tôi tiến hành đề tài với mục tiêu sau: "Nghiên cứu một số đặc điểm dịch tễ, lâm sàng, cận lâm sàng trẻ viêm phổi nặng có nhiễm vi rút hợp bào hô hấp”.

\section{2. Đối tượng và phương pháp nghiên cứu}

\section{1. Đối tương nghiên cứu}

Bao gồm các bệnh nhân từ 1 tháng đến 15 tuổi nhập viện tại Trung tâm Hô hấp Bệnh viện Nhi Trung ương được chẩn đoán viêm phổi nặng và có nhiễm RSV trong thời gian từ 01/06/2019-31/12/2019.

* Tiêu chuẩn viêm phổi theo WHO (2013) [5]:

$\checkmark$ Có viêm phổi: ho hoặc khó thở kèm theo một trong các dấu hiệu

+ Thở nhanh

+ Rút lõm lồng ngực

+ Nghe phổi có bất thường

$\checkmark$ Có dấu hiệu nặng: có 1 trong các dấu hiệu

+ Tím trung ương hoặc độ bão hòa oxy qua da $\mathrm{SpO}_{2}<90 \%$

+ Khó thở nặng: thở rên, rút lõm lồng ngực nặng

+ Có dấu hiệu nguy hiểm toàn thân

- Bỏ bú hoặc không uống được

- Li bì khó đánh thức

- Co giật

* Tiêu chuẩn chẩn đoán có nhiễm RSV: Xét nghiệm dịch hô hấp (dịch tỵ hầu, dịch nội khí quản) tìm RSV bằng phương pháp Quick test hoặc PCR tại trung tâm Vi sinh Bệnh viện Nhi Trung ương dương tính.

* Tiêu chuẩn loại trừ: Loại bỏ khỏi nghiên cứu các trường hợp sau:

$\checkmark$ Viêm tiểu phế quản

$\checkmark$ Viêm phổi không nặng

$\checkmark$ Lứa tuổi< $<1$ tháng hoặc $>15$ tuổi

$\checkmark$ Gia đình không hợp tác nghiên cứu

\subsection{Phưong pháp nghiên cứu}

2.2.1. Thiết kế nghiên cứu: Thiết kế mô tảtiến cứu

2.2.2. Cỡ mẫu: Cỡ mẫu thuận tiện

2.2.3. Cách thức nghiên cứu: Các trẻ nằm viện tại trung tâm hô hấp trong thời gian nghiên cứu đủ tiêu chuẩn chẩn đoán viêm phổi nặng và có xét nghiệm RSV dương tính tại lúc vào viện hoặc trong quá trình nằm viện. Mẫu bệnh phẩm làm xét nghiệm RSV được lấy từ các dịch hô hấp (dịch tỵ hầu, dịch nội khí quản)

2.2.4. Xử lý số liệu: Sử dụng phần mềm SPSS 20.0.

\section{Kết quả nghiên cứu}

Trong thời gian từ 01/06/2019 đến 31/12/2019 có 250 bệnh nhân đủ tiêu chuẩn chẩn đoán viêm phổi nặng có nhiễm RSV được đưa vào nghiên cứu. Tổng số bệnh nhân nhập viện điều trị nội trú tại Trung tâm Hô hấp trong 6 tháng cuối năm là 3473 bệnh nhân. Như vậy tỷ lệ viêm phổi nặng có nhiễm RSV chiếm 7,2 \% các trường hợp nhập viện tại Trung tâm Hô hấp 6 tháng cuối năm 2019. Cụ thể, chúng tôi thu được kết quả như sau:

Tỷ lệ mắc bệnh theo giới: 


\section{tỷ lệ nam/nữ}

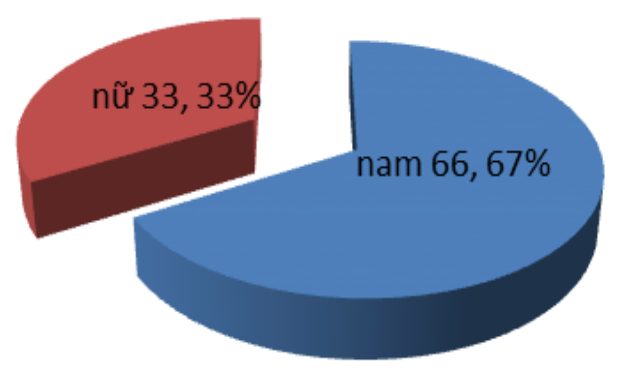

Hình 1. Tỷ lệ mắc bệnh theo giới.

Nhận xét: Nam mắc bệnh nhiều hơn nữ, tỷ lệ nam/nữ là 2/1Tuổi nhập viện trung bình 4,94 $\pm 6,04$ tháng tuổi, nhỏ nhất là 1 tháng tuổi và lớn nhất là 3 tuổi.

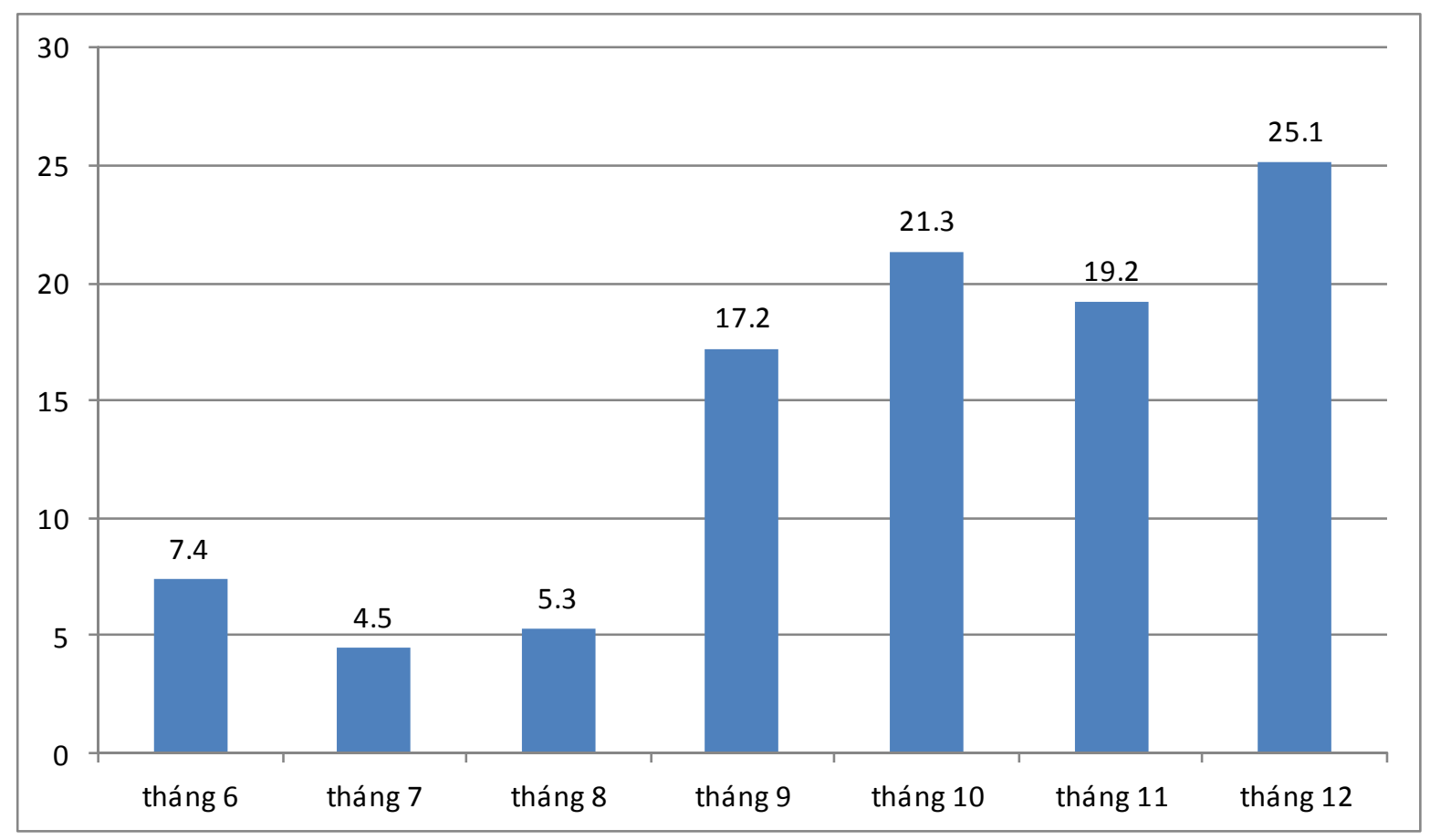

Hình 2. Tỷ lệ mắc bệnh theo tháng.

Nhận xét: Tỷ lệ mắc bệnh rải rác tất cả các tháng, có xu hướng tăng dần và cao nhất là tháng 12. 
Bảng 1. Triệu chứng cơ năng viêm phổi nặng có nhiễm RSV

\begin{tabular}{|l|c|c|}
\hline Triệu chứng & Bệnh nhân & Tỷ lệ \% \\
\hline Sốt & 47 & 18,8 \\
\hline Khò khè & 228 & 91,2 \\
\hline Ho & 204 & 81,6 \\
\hline Sổ mũi & 231 & 92,4 \\
\hline Khó thở & 250 & 100 \\
\hline Ăn kém & 234 & 93,6 \\
\hline
\end{tabular}

Nhận xét: Ho, khò khè, chảy mũi, ăn kém là những triệu chứng cơ năng hay gặp khiến trẻ phải đi khám và nhập viện. Sốt là triệu chứng gặp với tần suất ít hơn. Khó thở là triệu chứng gặp ở $100 \%$ các bệnh nhân nhập viện.

Bảng 2. Triệu chứng thực thể viêm phổi nặng nhiễm RSV

\begin{tabular}{|c|c|c|c|}
\hline \multicolumn{2}{|c|}{ Triệu chứng $\quad$ Bệnh nhân } & Tổng số & Tỷ lệ \% \\
\hline \multicolumn{2}{|c|}{ Thở nhanh so với lứa tuổi } & 250 & 100 \\
\hline \multicolumn{2}{|l|}{ Tím } & 12 & 4,8 \\
\hline \multicolumn{2}{|c|}{ Rút lõm lồng ngực } & 236 & 94,4 \\
\hline \multicolumn{2}{|l|}{ Ran ẩm, ran rít } & 242 & 96,8 \\
\hline \multirow{2}{*}{$\mathrm{SpO}_{2}$ không $\mathrm{O}_{2}$} & $<90 \%$ & 195 & 78 \\
\hline & $90-95 \%$ & 55 & 22 \\
\hline
\end{tabular}

Nhận xét: Các triệu chứng thở nhanh, RLLN, ran ở phổi hầu hết có ở các bệnh nhân viêm phổi nặng nhiễm RSV. Phần lớn các trẻ có nồng độ Oxy thấp lúc vào viện với $78 \%$ trẻ có $\mathrm{Sp}_{2}$ dưới $90 \%$. Tím tái gặp ở 4,8\% trường hợp.

Bảng 3. Một số yếu tố liên quan đến viêm phổi nặng nhiễm RSV

\begin{tabular}{|l|c|c|}
\hline \multicolumn{1}{|c|}{ Một số yếu tố liên quan } & Tổng số & Tỷ lệ \% \\
\hline Đẻ non & 62 & 24,8 \\
\hline Suy dinh dưỡng & 78 & 31,2 \\
\hline LSPQP & 31 & 12,4 \\
\hline Bệnh lý thần kinh & 15 & 6 \\
\hline Không được bú mẹ & 39 & 15,6 \\
\hline
\end{tabular}


Nhận xét: Trong số các trẻ VP nặng nhiêm RSV nhập viện, tỷ lệ trẻ đẻ non, suy dinh dưỡng, LSPQP gặp với tỷ lệ lần lượt là $24,8 \%, 31,2 \%, 12,4 \%$.

Bảng 4. Đặc điểm công thức máu và $\mathrm{CRP}$ của bệnh nhân khi vào viện

\begin{tabular}{|l|c|}
\hline Chỉ số & Bệnh nhân \\
\hline BC (G/L) & $14,07 \pm 4,08(2,80-40,9)$ \\
\hline BC Trung tính (G/L) & $5,74 \pm 3,51(0,10-27,00)$ \\
\hline BC Lympho( G/L) & $3,59 \pm 2,54(0,40-14,40)$ \\
\hline CRP (mg/dl) & $19,75 \pm 34,32(0,1-182)$ \\
\hline
\end{tabular}

Nhận xét:- Bệnh nhân có số lượng bạch cầu $\leq 10 \mathrm{G} / \mathrm{L}$ là 141 bệnh nhân $(56,4)$, bệnh nhân có số lượng

bạch cầu $>10 \mathrm{G} / \mathrm{L}$ là 109 bệnh nhân $(43,6 \%)$ với số lượng $\mathrm{BC}$ trung bình 14,07 \pm 4,08G/L. Bệnh nhân có chỉ số $\mathrm{CRP} \leq 6 \mathrm{mg} / \mathrm{dl}$ là 162 bệnh nhân $(64,8 \%)$, bệnh nhân có chỉ số CRP $>6 \mathrm{mg} / \mathrm{dl}$ là 88 bệnh nhân $(35,2 \%)$ với chỉ số trung bình là $19,75 \pm 34,32 \mathrm{mg} / \mathrm{dl}$.

Bảng 5. Đặc điểm khí máu

\begin{tabular}{|l|c|c|}
\hline Đặc điểm khí máu & Tổng số & Tỷ lệ \% \\
\hline Giảm Oxy & 38 & 15,2 \\
\hline Tăng CO2 & 148 & 59,2 \\
\hline Hỗn hợp & 64 & 25,6 \\
\hline
\end{tabular}

Nhận xét: Biến đổi trên khí máu hay gặp nhất là tình trạng tăng $\mathrm{CO}_{2}$.

Bảng 6. Đặc điểm Xquang phổi của bệnh nhân khi vào viện

\begin{tabular}{|l|l|c|c|}
\hline \multicolumn{2}{|c|}{ Bệnh nhân Xquang } & Tổng số & Tỷ lệ \% \\
\hline \multirow{4}{*}{ Tổn thương phổi } & mờ đám/rải rác & 162 & 64,8 \\
\cline { 2 - 4 } & kẽ & 23 & 9,2 \\
\cline { 2 - 4 } & thùy & 10 & 4 \\
\cline { 2 - 4 } & ứ khí & 67 & 26,8 \\
\hline
\end{tabular}

Nhận xét: Bệnh nhân có tổn thương phổi dạng đám mờ tập trung hay rải rác chiếm $64,8 \%$, ứ khí $26,8 \%$, tổn thương phổi kẽ $9,2 \%$, tổn thương dạng thùy $4 \%$.

Bảng 7. Kết quả cấy dịch tỵ hầu

\begin{tabular}{|l|c|c|}
\hline Kết quả cấy dịch tỵ hầu & Số lượng & Tỷ lệ \\
\hline Âm tính & 196 & $78,4 \%$ \\
\hline $\begin{array}{l}\text { Dương tính } \\
\text { Gram âm } \\
\text { Gram dương }\end{array}$ & 40 & $16 \%$ \\
\cline { 2 - 3 } & 14 & $5,6 \%$ \\
\hline
\end{tabular}


Nhận xét: Tỷ lệ cấy vi khuẩn dương tính chiếm $21,6 \%$, trong đó chủ yếu là vi khuẩn gram âm (40/54 trường hợp, chiếm 74,1\%).

Bảng 8 . Kết quả điều trị chung

\begin{tabular}{|l|c|c|}
\hline \multicolumn{1}{|c|}{ Bệnh nhân } & Tổng số & Tỷ lệ \% \\
\hline Khỏi - Đỡ giảm & 173 & 69,2 \\
\hline Chuyển viện (trong tình trạng đỡ hơn) & 12 & 30,8 \\
\hline Tử vong - Xin về & 0 & 0 \\
\hline
\end{tabular}

Nhận xét: Tỷ lệ chữa khỏi và đỡ giảm chiếm $100 \%$. Trong thời gian nghiên cứu chưa ghi nhận trường hợp nào tử vong. Thời gian nằm viện trung bình $6,2 \pm 7,4$ ngày. Thời gian thở oxy trung bình 4,7 $\pm 5,9$ ngày.

\section{Bàn luận}

Tỷ lệ nhiễm RSV trong 6 tháng cuối năm 2019 ở các trường hợp mắc viêm phổi nặng là 7,2\%. Con số này chưa bao gồm các trường hợp viêm phổi không nặng và viêm tiểu phế quản. Điều này cho thấy RSV là căn nguyên quan trọng gây viêm phổi ở trẻ. Vềgiới tính, số trẻ nam nhiều hơn số trẻ nữ, tỷ lệ nam/nữ = 2/1. Có thể do thực tế hiện nay, trẻ nam được sinh ra nhiều hơn so với trẻ nữ.

Tỷ lệ mắc RSV tăng cao ở tháng 12 do thời tiết lạnh ẩm. Trong 1 nghiên cứu 117 bệnh nhân nhi dưới 18 tuổi của Huijskens và cộng sự tại Netherlands năm 2012 tác giả cũng thấy rằng tỷ lệ phân lập được vi rút, đặc biệt là RSV cao nhất từ tháng 11 đến tháng 2 năm sau [6].

Trong nghiên cứu của chúng tôi, tỷ lệ trẻ dưới 6 tháng chiếm tới 44,7\%. Nghiên cứu của chúng tôi có kết quả tương tự so với Đào Minh Tuấn và cộng sự, trẻ < 6 tháng chiếm 62,5\% (năm 2013), chiếm 60,34\% (năm 2014) [7].

Các triệu chứng lâm sàng là các triệu chứng điển hình của viêm phổi và ở mức độ nặng.Nghiên cứu của Dan Peng và Van de Zalm cũng thấy rằng ho khan hoặc ho xuất tiết nhiều dịch nhầy $(71,9-67,7 \%)$, khò khè $(41,1 \%)$, chảy nước mũi $(61,6 \%)$, thở nhanh theo tuồi, khó thở, co rút lồng ngực, cánh mũi phập phồng, đầu gật gù theo nhịp thở, co kéo cơ liên sườn, rút lõm hõm ức $(53,1 \%)[8,9]$.

Một số yếu tố liên quan đến mắc viêm phổi nặng có nhiễm RSV có thể kể đến như tình trạng đẻ non, SDD, LSPQP, không được nuôi dưỡng bằng sữa mẹ. Tuy nhiên cần thêm các nghiên cứu so sánh với nhóm chứng để khẳng định.

Tổn thương trên phim chụp Xquang phổi cho thấy, đa số bệnh nhân có tổn thương phổi dạng đám mờ tập trung hay rải rác chiếm $64,8 \%$, tổn thương phổi kẽ $9,2 \%$, ứ khí 26,8\%, tổn thương dạng thùy $4 \%$. Kết quả này gần tương tự với nghiên cứu trên 210 bệnh nhi viêm phổi của tác giả $\mathrm{W}$ Guo và cộng sự năm 2012. Nghiên cứu chỉ ra, bệnh nhân có tổn thương mờ 2 bên phổi $63,33 \%$, tổn thương dạng kẽ 15,71\%, dạng thùy 7,14\%, ứ khí 13,82\% [10].

Tỷ lệ đồng nhiễm vi khuẩn được ghi nhận chắc chắn ở $21,6 \%$ bệnh nhân. Tỷ lệ cấy âm tính rất cao, tuy nhiên chưa loại trừ các trường hợp âm tính giả. Trong đó chủ yếu là các vi khuẩn gram âm (chiếm 
74,1\%). Có thể do các bệnh nhân đã nằm viện ở các tuyến dưới trước khi lên Bệnh viện Nhi Trung ương, điều này cho thấy nhiễm khuẩn bệnh viện là một trong các yếu tố làm tăng thêm tình trạng nặng của bệnh nhân.

$100 \%$ trẻ được điều trị khỏi hoặc đỡ để chuyển tuyến với thời gian nằm viện trung bình $6,2 \pm 7,4$ ngày, trong đó thời gian thở oxy trung bình là $4,7 \pm 5,9$ ngày. Thời gian nằm viện trung bình của chúng tôi thấp hơn so với nghiên cứu của Nguyễn Thị Ngọc Trân là 15,71 ngày khi nghiên cứu về viêm phổi do vi rút nói chung [9]. Trong nghiên cứu này, nhóm tác giả cũng ghi nhận những trường hợp viêm phổi nặng , đặc biệt liên quan tới adenovi rút , hoặc đồng nhiễm nhiều vi rút, vi rút và vi khuẩn cùng lúc , có thể do đó thời gian nằm viện kéo dài hơn . Trong khi nghiên cứu của chúng tôi chỉ lấy các trường hợp nhiễm RSV , các trường hợp xét nghiệm vi rút khác dương tính kèm theo không lấy vào nghiên cứu. Hầu hết các bệnh nhân bỏ oxy được 1-2 ngày sẽ được xuất viện về nhà hoặc chuyển tuyến do tình trạng quá tải, cần giải phóng bệnh nhân tại Trung tâm hô hấp.

\section{Kết luận}

Nghiên cứu của chúng tôi rút ra 1 số kết luận sau:

Tỷ lệ nhiễm RSV gia tăng 6 tháng cuối năm 2019. Tỷ lệ viêm phổi nặng có nhiễm RSV so với tổng số ca nhập viện tại Trung tâm Hô hấp 6 tháng cuối năm 2019 là 7,2 $\%$. Điều này cho thấy RSV rất dễ lây lan thành dịch. Trẻ nhập viện chủ yếu là ở nhóm trẻ dưới 1 tuổi, với các triệu chứng nặng, suy hô hấp nặng ở các mức độ khác nhau.

$100 \%$ các bệnh nhân nhập viện đều có triệu chứng khó thở. Phần lớn các trẻ có nồng độ
Oxy thấp lúc vào viện với $78 \%$ trẻ có $\mathrm{Sp} 0_{2}$ dưới $90 \%$

Thời gian nằm viện trung bình $6,2 \pm 7,4$ ngày, trong đó thời gian thở oxy trung bình 4,7 \pm 5,9 ngày. Một số yếu tố liên quan như đẻ non, suy dinh dưỡng, loạn sản phế quản phổi làm gia tăng tỷ lệ mắc RSV và mức độ nặng ở các trẻ viêm phổi nhập viện.

\section{Tài liệu tham khảo}

[1] Simoes EAF, Cherian T, Chow J et al. Acute Respiratory Infections in Children. In: Jamison DT, Breman JG, Measham AR, et al., editors. Disease Control Priorities in Developing Countries. 2nd edition. Washington (DC): The International Bank for Reconstruction and Development The World Bank; 2006.

[2] WHO, UNICEF. Global Action Plan for Prevention and Control of Pneumonia (GAPP); 2008.

[3] Pavia AT. Viral infections of the lower respiratory tract: old viruses, new viruses, and the role of diagnosis. Clin Infect Dis 2011;52(4):S284-9. https://doi.org/10.1093/ cid/cir043.

[4] Nair H, Nores DJ, Gessner BD et al. Global burden of acute lower respiratory infections due to respiratory syncytial virus in young children: a systematic review and meta analysis. Lancet 2010;375(9725):1545 1555. https://doi.org/10.1016/S0140-6736 (10)60206-1.

[5] WHO. Cough or difficult breathing. Pocket book of hospital care for children; 2005, p. 69-106.

[6] Huijskens EG, Biesmans RC, Buiting AG et al. Diagnostic value of respiratory virus detection in symptomatic children using realtime PCR. Virology Journal 2012;9:276. https://doi.org/10.1186/1743-422X-9-276.

[7] Tuan DM, Tran NTN. Some clinical, subclinical, and clinical epidemiological characteristics of severe acute lower 
respiratory tract infections in children in the Department of Respiratory of the Vietnam National Children's Hospital in 2013 and 2014. Vietnam Journal of Medicine. 2012; 436:28-33. (in Vietnamese).

[8] Peng D, Zhao D, Liu J et al. Multipathogen infections in hospitatized children with acute respiratory infections. Virol J 2009;6:155. https://doi.org/10.1186/1743422X-6-155
[9] Van der Zalm MM, van Ewijk BE, Wilbrink B et al. Respiratory pathogens in children with and without respiratory symptoms. J Pediatr 2009;154(3):396-400. https://doi.org/10.1016/j.jpeds.2008.08.036.

[10] Guo W, Wang J, Sheng $M$ et al. Radiological findings in 210 paediatric patients with viral pneumonia: a retrospective case study. Br J Radiol 2012; 85(1018):1385-1389. https://doi.org/10.125 9/bjr/20276974 